\title{
Aging, Asset Allocation, and Costs: Evidence for the Pension Fund Industry in Switzerland
}

David S. Gerber and René Weber 



\title{
IMF Working Paper
}

\author{
Office of the Executive Director
}

\section{Aging, Asset Allocation, and Costs: \\ Evidence for the Pension Fund Industry in Switzerland}

Prepared by David S. Gerber and René Weber ${ }^{1}$

Authorized for distribution by Thomas Moser

February 2007

\begin{abstract}
This Working Paper should not be reported as representing the views of the IMF. The views expressed in this Working Paper are those of the author(s) and do not necessarily represent those of the IMF or IMF policy. Working Papers describe research in progress by the author(s) and are published to elicit comments and to further debate.

This paper focuses on the nexus between pension funds' balance sheet liabilities, reflecting their age profile and payments obligations, and the investment behavior and costs of these funds. The context of the analysis is the stringent regulatory framework and the highly fragmented and heterogeneous pension fund landscape in Switzerland. Detailed data from the Swiss Pension Statistic are analyzed using multivariate OLS-regressions. The evidence shows that a younger age structure and lower short-term benefits payouts are related to a higher share of equities and lower real estate holdings. Legal form, pension plan type, and size are important for administrative costs. The findings support the view that aging may lead to increased risk aversion and thus to a lower engagement of institutional investors in equities.
\end{abstract}

JEL Classification Numbers: G23, G28, J26, J32

Keywords: Aging, asset allocation, pension system, Switzerland

Authors’ E-Mail Addresses: david.gerber@efv.admin.ch; rweber@imf.org

\footnotetext{
${ }^{1}$ David S. Gerber is Head of Section for Financial Markets and Financial Services in the Swiss Federal Finance Administration, René Weber is Senior Advisor to Executive Director at the IMF. The authors particularly thank Jürg Fuhrer and Paul Hess of the Swiss Federal Statistical Office for their assistance, as well as Carsten Colombier, Daniel Hardy, Martin Hess, Christoph Lieb, Thomas Moser, Kevin Ross, and Bob Traa for their comments. This analysis was initially prepared as background for the report prepared at the request of the G-10 Deputies on "Ageing and Pension System Reform: Implications for Financial Markets and Economic Policies" published in September 2005.
} 


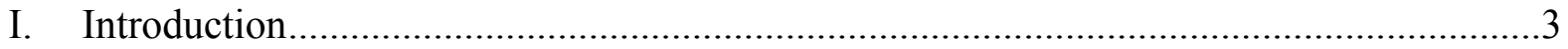

II. Institutional Framework for the Swiss Pension Fund Industry........................................5

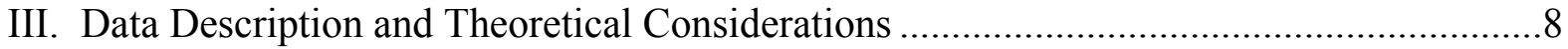

A. Data Set and Characteristics of the Swiss Pension Fund Landscape .......................8

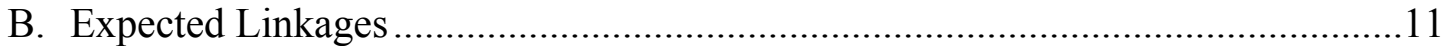

IV. Results: What Determines the Asset Allocation and Costs of Pension Funds?...............13

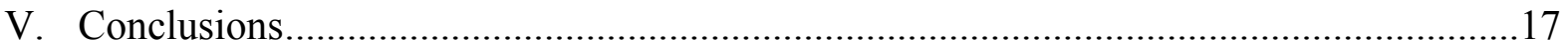

Tables

1. Risk Coverage and Risk Transfer of Pension Funds ...............................................6

2. Aggregate Evidence for the Swiss Pension Fund Industry ....................................

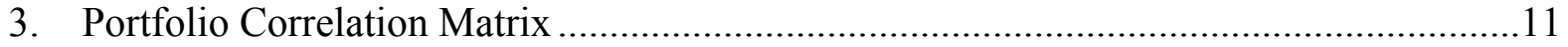

4. OLS-Regressions: Influence of the Explanatory Variables .......................................... 14

5. Reaction Analysis for Equity Holdings ................................................................... 16

Figures

1. Systemic Parameters and Economic Linkages within the Swiss Second Pillar ................8

Appendices

I. Key Indicators from the Swiss Pension Statistic .....................................................19

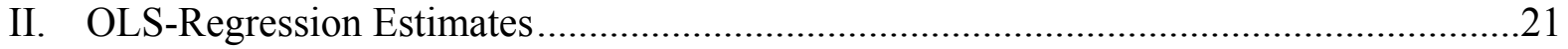

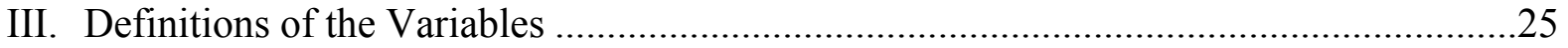

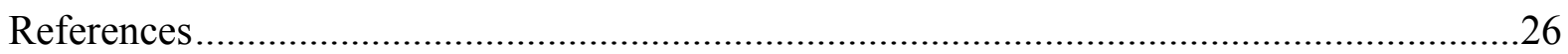




\section{INTRODUCTION}

Switzerland has since 1985 a mandatory, funded occupational ("second pillar") pension system. With total assets under management in this employer-based system of about CHF 600 billion $^{2}$, Switzerland is one of very few countries with private pension savings exceeding 100 percent of GDP (135 percent in 2004). This is the main reason why Switzerland is regarded as being relatively well prepared for the demographic challenges all industrialized countries are confronted with (to different degrees) over the next decades.

An aging population is likely to affect funded pension systems through three main channels. First, given a regulatory framework that requires pension funds to take into account both assets and liabilities in their investment strategy, aging is bound to have an impact on the asset allocation of pension funds. This in turn will affect expected returns. Second, as the baby boom generation will start retiring and claim old-age benefits payouts, pension funds are likely to sell assets, thereby exerting downward pressure on asset prices. ${ }^{3}$ Third, aging might also lead to a change in relative prices due to higher demand for goods and services that an aging society consumes more. If monetary policy accommodates this higher demand, overall inflation might also increase. Such rising inflation reduces the purchasing power of pensions. This is for instance pointed out by Barr (2002). According to the OECD (2004), however, neither an "asset meltdown" scenario nor strong inflation due to aging seem plausible developments.

The present paper focuses on the first of these channels. Since pension funds as institutional investors are an important investor class, their behavior affects the markets for financial assets, including their pricing. The analysis looks at pension funds' balance sheet liabilities as a determinant of capital allocation among different asset classes such as equities, bonds, and real estate (strategic asset allocation). The funds' balance sheet liabilities, in turn, reflect the age profile of the funds' membership and expected benefits payouts. However, the paper does not consider how the possibility to choose between domestic and foreign assets influences these relationships. ${ }^{4}$ Further steps in the investment process, such as short-term over- or underweighting of asset classes (tactical asset allocation), the selection of securities, or the choice between internal or external fund managers, also lie outside the scope of this paper.

Since funded pension systems are set up according to distinct country-specific regulatory frameworks, knowledge on the determinants of pension funds investment decisions, and on the outcome of these decisions, is clearly policy relevant. Regulation, including accounting rules, influences the ability of pension funds to build up reserves and thus their capacity to bear market risks. Misguided regulation may lead to suboptimal risk-return profiles. Also,

\footnotetext{
${ }^{2}$ In 2004 according to official statistics, CHF 484 billion were managed by pension funds and CHF 121 billion by collective foundations of life insurers. This analysis focuses on the former group of pension service providers only.

${ }^{3}$ See Bakshi and Chen (1994), Poterba (2001), Börsch-Supan et al. (2002), Mc Morrow and Röger (2003), Davis and Li (2003), or Cai (2004).

${ }^{4}$ In 2004, the overall shares of foreign [domestic] assets held by Swiss pension funds were as follows: equity 14.9 [12.2] percent, bonds 17.2 [19.1] percent, real estate 0.5 [17.7] percent. Federal Statistical Office (2006).
} 
these rules determine how pension funds will react in case of a fall in asset prices, possibly inducing a pro-cyclical sell-off of risky assets. Furthermore, with the widespread application of asset liability management (ALM) techniques in handling the large and growing pool of retirement savings, the aspect of prudential supervision over this segment of the financial industry has gained in importance. Effective pension supervision regimes need to consider the incentives inherent in the system and those stemming from regulatory activity.

Empirical evidence on the linkages between pension funds' liabilities and their asset allocation is scarce. Campbell and Viceira (2002) survey the literature on strategic asset allocation for long-term investors and show under what conditions the investment horizon matters for optimal portfolio choice. The authors predict that younger investors are likely to invest more in equities. If these investors are conservative, they are bound to hold large positions in inflation-indexed bonds (if available) or long-term bonds (if investors believe that inflation risk is low). Alestalo and Puttonen (2006) present evidence for Finnish pension funds. They find that pension funds with younger members have a higher equity exposure and pension funds with a more mature age profile hold a higher share of fixed income instruments.

Liabilities are also bound to affect the costs of pension funds. A higher share of benefits recipients relative to contributing (i.e. active) members will likely increase administrative expenses. There will be a larger number of individual benefits payouts requiring additional inquiries on individual recipients, while contributions are largely automatic via payroll deductions. Other overhead costs such as spending on IT, rents, or external expert opinions also matter. Furthermore, a pension fund's asset management affects its expenses since the costs of investing in different asset classes vary. There is a substantial literature that analyzes the costs related to administering individual accounts. ${ }^{5}$ In employer-based systems in which employees cannot freely choose their pension fund, as in Switzerland, the cost structure of these funds differs markedly from those of providers of similar (substitutive) products such as mutual funds that operate in a competitive environment. Under these circumstances, pension funds' costs are determined for example by the administrative efficiency and the professional know-how of pension fund managers, the age profile of its members, and the investment strategy pursued; marketing costs on the other hand are less important.

This paper therefore addresses two questions:

- First, does the liability side in the balance sheet of Swiss pension funds affect their asset allocation strategy, and, in particular, do pension funds with a more mature age profile invest more conservatively?

- Second, do differences on the liability side and the asset allocation also influence the costs of Swiss pension funds and in what way?

In order to answer these questions empirically, the paper is organized as follows. Section II briefly describes the institutional framework for the highly fragmented and heterogeneous Swiss occupational pension system, including the main regulatory parameters that determine pension funds' investment choices and their costs. Section III describes the data used for the

\footnotetext{
${ }^{5}$ See for example Diamond (1999) or James et al. (1999).
} 
empirical analysis and highlights the key characteristics of the Swiss pension fund landscape. It also includes theoretical considerations on the determinants of portfolio choice and cost factors of pension funds. Section $I V$ presents the findings of the multivariate regression analysis. Section $V$ offers concluding remarks.

\section{InStitutional Framework for the Swiss Pension Fund Industry}

The basis for the Swiss occupational pension system was laid in the late $19^{\text {th }}$ century by benevolent industrialists who introduced pension arrangements for their employees. The subsequent expansion of both the number of employees covered and the volume of assets accumulated during the $20^{\text {th }}$ century was also a consequence of early preferential tax treatment. The adoption of the Federal Law on Occupational Pension Schemes (LPP) in the mid-1980s, that made second pillar contributions for employers and employees mandatory, was thus an evolutionary step, building on an already largely established system.

The LPP allows for different institutional setups and types of pension funds. One of the most notable characteristics of the Swiss second pillar is thus its variety: it is highly fragmented and heterogeneous. These characteristics also have a bearing on the empirical analysis in Section IV that needs to be appropriately "granular":

(i) There is a distinction to be made between pension funds that are authorized by the federal authorities to provide the mandatory part of the second pillar in full accordance with the provisions of the LLP (registered pension funds) and those that only offer pensions insurance above the legal minimum (non-registered pension funds). The former dominate both in terms of insured persons and assets managed.

(ii) Pension providers can take different legal forms. In 2004 about 17 percent of those insured within the second pillar belonged to pension funds under public law. These funds may profit from implicit or explicit public guarantees, allowing them to maintain funding levels considerably below 100 percent. ${ }^{6}$ The large majority of employees insured in the second pillar were members of pension funds under private law. These funds usually take the legal form of a foundation and only rarely the form of a cooperative. $^{7}$

(iii) The risks that are covered and transferred also vary (see Table 1). Autonomous funds bear all relevant risks (i.e. longevity, death, and disability) alone or with reinsurance, whereas partly autonomous funds transfer the invalidity and/or longevity risk to life insurance companies. Collective pension funds, for their part, have entered a collective contract with a life insurance company under which the latter assumes all risks.

(iv) There has been a shift out of defined benefit plans (DB) into defined contribution plans (DC) over the last few years that is ongoing. Today, more than three quarters of employees are members of a DC plan. Defined benefit plans are still maintained by some large corporations and by most pension funds under public law.

\footnotetext{
${ }^{6}$ For a definition of such underfunding see Footnote 11.

${ }^{7}$ Generally, pension funds in Switzerland are separate legal entities from the employer and their assets and liabilities are not part of the balance sheet of the employer.
} 
(v) The relationship between employers and their pension provider is also not uniform. It is common that several (related or unrelated) employers are affiliated with a pension fund, for example as part of an industry grouping.

Table 1. Risk Coverage and Risk Transfer of Pension Funds

\begin{tabular}{|c|c|c|c|}
\hline Pension funds & Risks outsourced & $\begin{array}{c}\text { Number of } \\
\text { institutions } \\
\text { (2004) }\end{array}$ & $\begin{array}{l}\text { Insured } \\
\text { persons in \% } \\
\text { of total } \\
(2004) \\
\end{array}$ \\
\hline Autonomous 1 & cover all risks (longevity, death, and disability) & 461 & 38.3 \\
\hline Autonomous 2 & $\begin{array}{l}\text { cover all risks with reinsurance (in form of excess- } \\
\text { loss or stop-loss insurance) }\end{array}$ & 559 & 13.4 \\
\hline $\begin{array}{l}\text { Partial auto- } \\
\text { nomous } 1\end{array}$ & $\begin{array}{l}\text { old-age pensions are paid by the pension fund; } \\
\text { collective contract with life insurance company } \\
\text { transferring disability and/or death risk }\end{array}$ & 673 & 8.1 \\
\hline $\begin{array}{l}\text { Partial auto- } \\
\text { nomous } 2\end{array}$ & $\begin{array}{l}\text { accumulation of the savings capital by the pension } \\
\text { fund (for lump sum benefits or the purchase of life- } \\
\text { time pensions from a life insurance company); } \\
\text { collective contract with life insurance company } \\
\text { transferring all other risks }\end{array}$ & 672 & 8.2 \\
\hline Collective & $\begin{array}{l}\text { collective contract with life insurance company } \\
\text { transferring all risks }\end{array}$ & 471 & 32.0 \\
\hline
\end{tabular}

Source: Federal Statistical Office (2006). In 2004, the total of insured persons was 3'208'914.

Besides the fact that the Swiss second pillar incorporates a wide variety of institutions, the legislation defines several pivotal systemic parameters as explained below: the insured wage, the envelope for employer and employee contributions, the minimum conversion rate, investment limitations, and the minimum interest rate. These parameters aim at ensuring a minimum benefit level for the employees, but in doing so also strongly influence pension funds' liabilities, their risk-taking, and investment behavior. ${ }^{8}$ They essentially determine what liabilities are assumed and how efficiently individual funds as well as the system as a whole allocate retirement savings.

The asset accumulation phase for the mandatory part of the second pillar is defined by law to be 40 years. Each employee earns age-group related retirement credits financed by employer and employee contributions. ${ }^{9}$ The governing body of a pension fund is free to determine the respective contributions to finance these credits, as long as the employer's contribution overall at least matches the sum the of employees' contributions. As part of the Swiss multipillar pension system, the second pillar old-age benefits must, together with the pay-as-you-

\footnotetext{
${ }^{8}$ Note that this is why Switzerland's DC pension funds could be classified as "hybrid" DB plans according to the new taxonomy of the Working Party on Private Pensions of the OECD (2005).

${ }^{9}$ Retirement credits are accumulated individually with a fixed percentage of the yearly insured wage per 10year age group. These credits amount to 7 percent (age 25-34), 10 percent (age 35-44), 15 percent (age 45-54), and 18 percent (age 55-64), summing up to 500 percent of the insured wage after 40 years of contributing into the pension plan.
} 
go pensions of the first pillar, amount to 60 percent of income. In order to reach this objective, a minimum conversion rate (i.e. benefit level as a percentage of the accumulated capital) for second pillar benefits is set by law. ${ }^{10}$

As in other countries, investment limitations for pension funds have been relaxed in Switzerland in the 1990s. The emphasis shifted from a reliance on quantitative restrictions for the different asset classes to a "prudent person" approach. Since 2000 the legislation allows a pension fund to deviate from the existing boundaries for the different asset categories if it can demonstrate adequate financial soundness and risk diversification. The supervisory authorities allow pension funds to be temporarily underfunded. ${ }^{11}$

While the asset side of the balance sheet reflects the investments of a pension fund, its liabilities are determined by the statutory minimum interest rate and the technical interest rate. The minimum interest rate is the minimum return on the mandatory accumulated savings that a pension fund must guarantee. ${ }^{12}$ The technical interest rate, on the other hand, is the assumed discount rate used for the calculation of the present value of future contributions and pension liabilities; its exact level is not fixed by law. ${ }^{13}$ The LPP also states that pension funds, in principle, have to fully incorporate price increases in mandatory survivors' and disability benefits, whereas old-age benefits must be adjusted according to the financial health of the pension fund. ${ }^{14}$

\footnotetext{
${ }^{10}$ Until 2005 the statutory conversion rate was 7.2 percent. In the context of the revision of the LPP the conversion rate has since been reduced to 6.8 percent and the Swiss government envisages to lower it further to 6.4 percent by 2011 .

${ }^{11}$ A pension fund is deemed underfunded if the present value of all future liabilities is higher than the value of its assets. In 2005, legislation entered into force that broadens the range of measures that heavily underfunded pension funds must take to rebuild their solvency margin (reserves). According to these provisions, such funds are permitted on a temporary basis to levy special employer and employee contributions, including contributions from pensioners under certain very strict limitations. In addition, they may pay interest at 0.5 percent below the statutory minimum interest rate. It is the pension fund's responsibility to decide upon these measures, but they can only be applied during a state of underfunding and should be appropriate with regard to the overall financial situation of the pension fund.

${ }^{12}$ From 1985 to 2002, the minimum interest rate remained unchanged at 4 percent. Since then it was handled more flexibly, with the Swiss Federal Council setting it at 3.25 percent for 2003, 2.25 percent for 2004, and 2.5 percent for 2005 and 2006.

${ }^{13}$ The Pension Rights Transfer Act of 1995 (Freizügigkeitsgesetz, FZG) stipulates that for the calculation of accrued benefits the technical interest rate must be set at 3.5 to 4.5 percent. An authorized second pillar expert sets this parameter for an individual pension fund within a range consistent with the long-term rate of return of a low-risk instrument (e.g. the 10-year Swiss Confederation Bond) or the average rate of return of the pension fund minus a safety margin. See Schweizerische Kammer der Pensionskassen-Experten (2005).

${ }^{14}$ It is the governing body of the pension fund (usually the foundation board), in which delegates of employer and employees are represented in equal number, that decides to what extent adjustments of old-age benefits to price increases are made.
} 
For illustrative purposes, Figure 1 shows the economically relevant systemic parameters and their linkages within the Swiss second pillar. Non-regulated systemic determinants are circled. The rectangles denote factors through which the legislator directly influences a pension fund's payments obligations and investment decisions. Circles in rectangles refer to systemic outcomes. Unlike in DC plans, the employees' contributions in DB plans are determined by the level of benefits specified. The diagram does not include the decentralized supervisory setup for the pensions industry, which is currently under reform.

Figure 1. Systemic Parameters and Economic Linkages within the Swiss Second Pillar

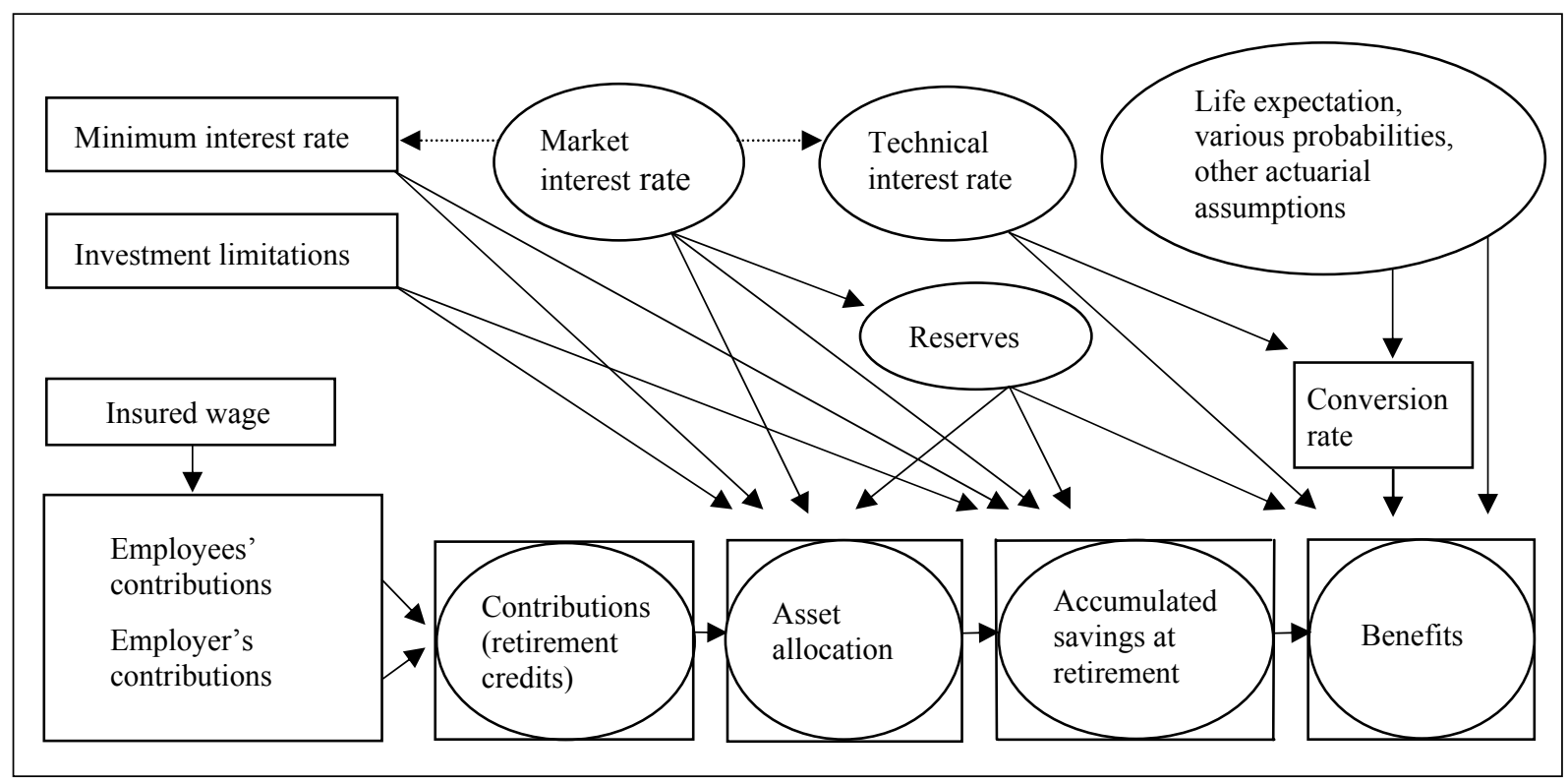

\section{DATA Description AND Theoretical Considerations}

\section{A. Data Set and Characteristics of the Swiss Pension Fund Landscape}

The empirical analysis is based on individual pension fund data from the Swiss Pension Statistic. The Swiss Federal Statistical Office collects this data with a biennial survey which all pension funds have to complete by law. The consolidated statistics compiled from the responses are published with a two-year lag, in aggregate form. ${ }^{15}$ The Swiss Pension Statistic is thus based on a comprehensive survey, which makes it representative for the industry. While the Federal Statistical Office ensures the comparability of the data, its quality and completeness depend on the reporting of the pension funds. For this analysis, detailed data for individual pension funds for the survey years 2000 and 2002 were obtained. This data base does not correspond to panel data, however.

\footnotetext{
${ }^{15}$ See Federal Statistical Office (2002, 2004, and 2006).
} 
The data for the year 2002 reflect a particularly difficult market environment. The Swiss Market Index (SMI) dropped by 21.1 percent in the year 2001 and by 27.8 percent in the year 2002. This was the main reason why, for the first time since the system was set up in 1985 and despite ongoing mandatory asset accumulation, the total volume of assets managed in the Swiss second pillar fell. This decline of CHF 50 billion between 2000 and 2002 was significant (from CHF 491 billion to CHF 441 billion, excluding assets in collective foundations of life insurance companies). ${ }^{16}$ In the meantime, the financial markets have recovered which has helped pension funds to rebuild their reserves.

Key indicators from the Swiss Pension Statistic using a number of key indicators are presented in Table 2 and in detail in Appendix I (Tables 6-9), with the definitions of the indicators given in Appendix III. This descriptive analysis allows for a comparison of the level of benefits as measured by different benefits ratios. It also gives an indication on the age profiles of the different types of pension funds. Furthermore, the most relevant positions within pension funds' portfolios as well as the reserve situation of the funds can be distinguished. Finally, cost indicators are also relevant for the present analysis. Table 2 highlights three salient facts for these indicators.

Table 2. Aggregate Evidence for the Pension Fund Industry

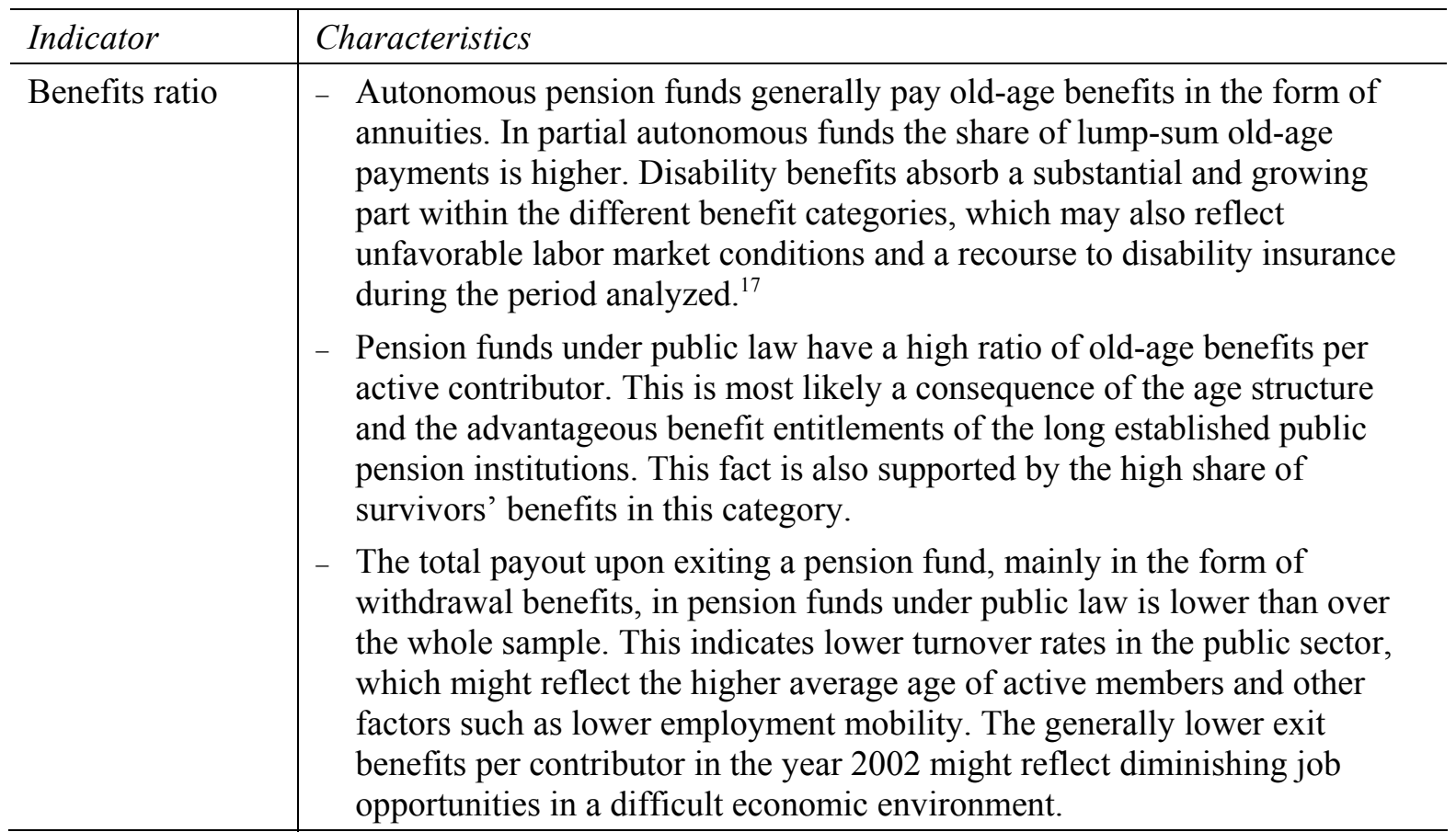

\footnotetext{
${ }^{16}$ Federal Statistical Office (2006).

${ }^{17}$ According to the Social Insurance Statistics of the Federal Office of Social Insurance (2003) the total number of disability benefits recipients in the first pillar increased by 13.6 percent between 2000 and 2002 .
} 


\begin{tabular}{|c|c|}
\hline Indicator & Characteristics \\
\hline Age profile & $\begin{array}{l}\text { - The median age of members over all categories increased markedly over the } \\
\text { two-year period from } 44.2 \text { to } 44.7 \text { years. } \\
\text { - The pension funds with the oldest membership are DB funds. Most of these } \\
\text { are set up under public law. } \\
\text { - The difference in the median age among pension funds types is smaller for } \\
\text { the subgroup of active contributors when compared to all pension fund } \\
\text { members (i.e. active contributors, disability benefits recipients, and old-age } \\
\text { pension recipients). }\end{array}$ \\
\hline $\begin{array}{l}\text { Asset holdings } \\
\text { and reserves }\end{array}$ & $\begin{array}{l}\text { From } 2000 \text { to } 2002 \text { the relative importance of equity decreased while the } \\
\text { preference for bonds, cash, and real estate rose, in line with the fall in stock } \\
\text { market valuations and declining interest rates. The divergence between the } \\
\text { different types of pension funds regarding both bond and equity holdings is } \\
\text { relatively small. } \\
\text { - The differences between private and public pension funds with regard to } \\
\text { cash and equity holdings are small. In comparison, public pension funds } \\
\text { invest more in real estate, primarily through direct investments and } \\
\text { mortgage loans for their employees. Private pension funds, on the other } \\
\text { hand, hold a higher share of bonds. } \\
\text { - Both cover ratios and reserves declined between } 2000 \text { and 2002, reflecting } \\
\text { adverse market conditions and the relatively stable or even increasing } \\
\text { liabilities of pension funds. }\end{array}$ \\
\hline Costs and size & $\begin{array}{l}\text { - Administrative expenses are lower for autonomous funds than for partial } \\
\text { autonomous funds (of type 1), even if these costs are put in relation to the } \\
\text { number of active contributors rather than to the total of benefits recipients. } \\
\text { The low costs for collective funds and partial autonomous funds (of type 2) } \\
\text { reflect the fact that these types of funds outsource central activities to life } \\
\text { insurers. Some of these expenses are covered by insurance premiums and } \\
\text { are not explicitly charged to the pension funds or are "subsidized" by excess } \\
\text { returns on assets by the insurer. }{ }^{18} \\
\text { - Public pension funds are shown to have lower administrative expenses than } \\
\text { private pension funds. } \\
\text { - The volume of assets managed differs greatly among the types of pension } \\
\text { funds. By this measure, autonomous, DB, and public funds are the largest } \\
\text { pension funds. This illustrates the importance and influence of outsourcing } \\
\text { and technical capacity. Bigger pension funds are likely to manage their } \\
\text { assets on their own, without resorting to a risk transfer to a life insurance } \\
\text { company. }\end{array}$ \\
\hline
\end{tabular}

${ }^{18}$ See Schmid (2004, p. 59).

${ }^{19}$ This finding is in line with evidence from other countries. See for example Allsopp and Barr (2006). 
With regard to asset holdings, a look at the relationships within pension funds' portfolios may provide additional insights. The correlation matrix in Table 3 shows the linkages among different asset classes as part of the portfolio mix, indicating a positive correlation between bond and equity investments. In contrast, both equity and bond shares are negatively correlated with cash and real estate holdings.

Table 3. Portfolio Correlation Matrix

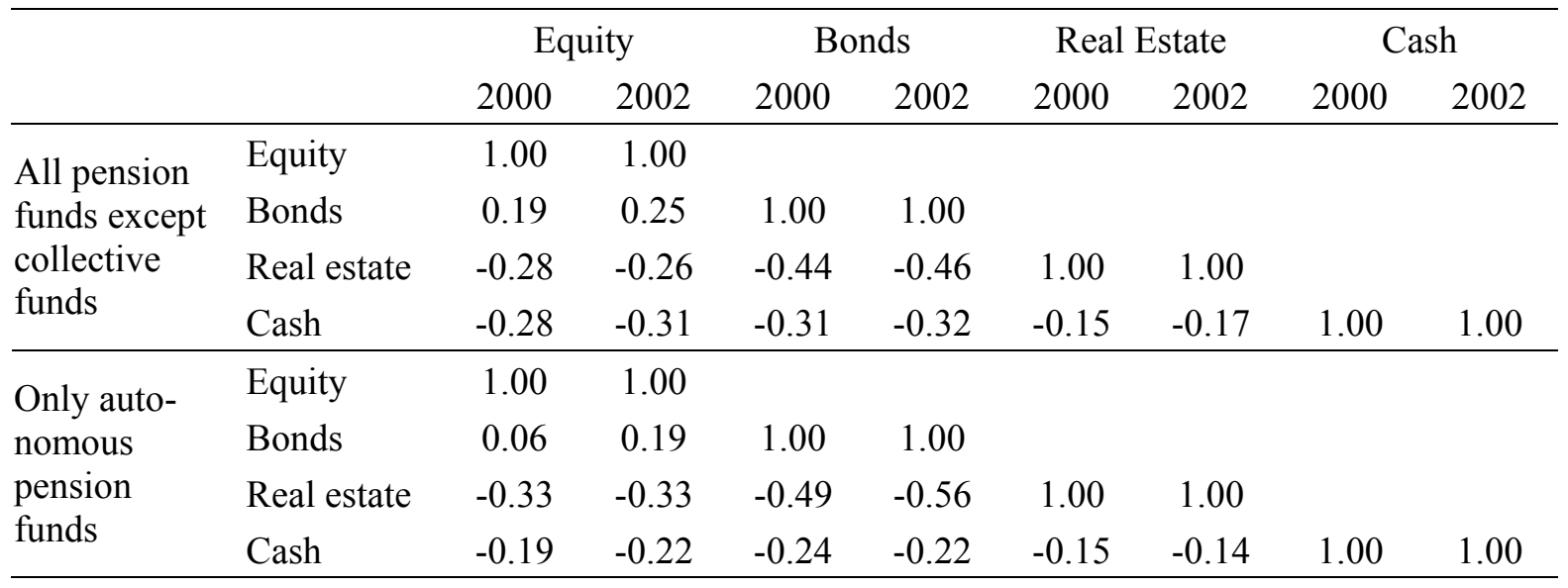

Notes:

See Appendix III for definitions. Correlation coefficients are shown.

\section{B. Expected Linkages}

The determinants of a pension fund's investment strategy are manifold. Since higher returns reduce the contribution rates of employees and employers given a targeted benefit level, return maximization is a central objective. Contribution smoothing might be another goal from an employer perspective. Regulatory authorities, for their part, influence pension funds' asset allocation decisions by putting a premium on a stable pension system. They usually oblige pension funds to ensure a certain funding level. In pursuing social policy objectives, regulators also often impose investment restrictions or minimum return guarantees.

The choice between different asset classes according to pension funds' liabilities is an outcome of the ALM process. Pension funds thereby consider both the asset and the liability side of the balance sheet in their investment decisions. There is no consensus in the literature on the optimal asset allocation of pension funds. The debate between those who advocate investing primarily in equities and those who favor bonds remains controversial, with the arguments focusing primarily on the trade-off between risk and return, the volatility characteristics of these instruments, and the probability to be able to meet contractual obligations. ${ }^{20}$ In this context, a third important asset class, real estate, must also be considered. Typically, investments in real estate are less volatile, offer a stable cash flow, and serve well for portfolio diversification purposes. On the downside, they yield lower returns than equity holdings. As evidenced by Chun et al. (2000) for pension funds in the U.S.,

${ }^{20}$ See for example Bodie (1995) or Feldstein (2005). 
however, only a very modest risk reduction can be realized from holding real estate in a portfolio.

The following briefly presents the expectations on the determinants of portfolio choice and cost factors of pension funds, bearing in mind the institutional framework of the Swiss pension fund industry described above.

\section{Determinants of Asset Allocation}

One would expect an older age structure of a pension fund to negatively influence the share of investments in riskier assets such as equity. Pension funds with a more mature age profile, and by definition fewer young and active members as contributors, face a shorter time horizon for their investments which limits the amount of market risk they are able to assume. The conservative investment bias due to a prudent investment strategy by "older" pension funds may be reinforced by a stagnant or even declining pool of assets to be managed. One might therefore expect pension funds with a higher average age to prefer risk-return profiles offered by bonds and real estate rather than equity.

One would expect variables indicative of short-term liabilities (i.e. payments obligations) to negatively influence the share of investments in riskier assets such as equity. In principle, higher short-term liabilities in the form of more benefits payouts increase the liquidity needs of a pension fund. These obligations thus require a higher share of cash or other liquid investments, while less capital should be invested in more volatile assets such as equities. Pension funds with a high number of old-age, disability, and survivors' benefits recipients are likely to choose a higher proportion of real estate investments that provides a regular and less fickle cash flow to cover benefits payments due. Higher short-term payments obligations also render a pension fund less able to respond to a market downturn, limiting its ability to take on risks.

One would expect the level of reserves to positively influence the share of investments in riskier assets such as equity. The ability to assume financial market risk increases with the funding cushion. Thus, one can expect a positive influence of reserves and cover ratios ${ }^{21}$ on equity holdings. This being said, there is the potential downside of a vicious circle. A significant stock market downturn can exhaust the reserves of pension funds and reduce their cover ratios. As a result, they are limited in their ability to bear market risks and are forced to sell equities into a falling market, thereby exacerbating price declines. ${ }^{22}$

\footnotetext{
${ }^{21}$ Reserves are the solvency margin expressed as a share of total assets. The cover ratio is the ratio between the assets and the present value of all future liabilities. These indicators are measures for the financial health of a pension fund.

${ }^{22}$ This happened in Switzerland between 2000 and 2002 when life insurers (and their collective foundations that provide pension services), which are required by law to guarantee a cover ratio of over 100 percent, reduced their equity shares from an estimated 25 percent to less than 5 percent. See Birchler and Allenspach (2003).
} 


\section{Determinants of Costs}

One would expect variables indicative of short-term liabilities (i.e. payments obligations) to positively influence administrative expenses. A higher number of individual benefits payouts falling due in the short-term points to increased administrative expenses of a pension fund. This is likely due to the costs of additional inquiries regarding individual recipients. These costs will be shouldered by pension funds' active members, rather than by the entire membership. In contrast, benefits recipients will overtly or covertly also contribute to asset management outlays.

One would expect the size of a pension fund in terms of assets managed to negatively influence administrative and asset management costs. Large pension funds should be able to reap economies of scale both in terms of a more efficient administration of individual accounts and a more sophisticated asset management (this includes bargaining power when contracting out such tasks). One could for example argue that with regard to real estate, bigger and medium-sized pension funds are more capable of investing directly than smaller funds. The size of a pension fund should therefore be negatively related to administrative and asset management costs.

One would expect the investment shares of different asset classes to positively influence asset management costs. Investment activities (changes in the investment volume but also the shifting of assets within this portfolio) will entail fees that add to asset management expenses. These costs are likely to be highest for real estate transactions for which the market is not as liquid and transparent as for securities.

\section{Other Factors}

Expectations regarding selected other variables can only be tentative. Referring to legal status (public or private), because pension funds under public law have (implicit) public guarantees and are allowed to be underfunded, they face fewer financial constraints. They may thus hold a notable equity share even without or with only a small reserve cushion. With regard to pension plan type (DB or DC), to the extent that DB plans include a redistributive element, the linkage between the age-related investment horizon and the asset allocation strategy of the pension fund could be weaker than in DC plans. These two factors are included in the empirical analysis as dummy variables.

\section{ReSults: What Determines the Asset Allocation AND Costs OF PENSION Funds?}

The following analysis seeks to empirically explore the expected relationships put forward in the previous section. In order to shed light on the determinants of pension funds' asset allocation and costs a series of multivariate OLS-regressions are run. The choice of variables in these models reflects the expectations formulated above. The estimations included 
techniques to ensure the robustness of the results. ${ }^{23}$ The findings of the regression estimates with equity shares, real estate holdings, administrative outlays, and asset management expenses as respective dependent variables are presented in condensed and qualitative form in Table $4 .{ }^{24}$ The table indicates the direction of the influence, i.e. the signs of the coefficients.

Table 4. OLS-Regressions: Influence of the Explanatory Variables

\begin{tabular}{|c|c|c|c|c|}
\hline Independent variable & Equity & $\begin{array}{l}\text { Real } \\
\text { estate }\end{array}$ & $\begin{array}{l}\text { Admini- } \\
\text { strative } \\
\text { expenses * }\end{array}$ & $\begin{array}{c}\text { Asset } \\
\text { management } \\
\text { expenses }\end{array}$ \\
\hline Average age (all members) & - & + & + & \\
\hline Average age (contributors) & - & & + & \\
\hline Disability beneficiaries' ratio & - & + & & \\
\hline Survivors' beneficiaries' ratio & - & + & + & \\
\hline Exit benefits ratio & + & - & + & \\
\hline Reserves & + & - & & \\
\hline Cover ratio & $+/-$ & - & & \\
\hline Law: Public & - & + & - & \\
\hline Plan type: DC & & & - & - \\
\hline $\operatorname{Size}^{* *}$ & - & - & + & - \\
\hline Equity & & & & + \\
\hline Real estate & & & & + \\
\hline Bonds & & & & + \\
\hline
\end{tabular}

Notes:

The table indicates the direction of the influence, i.e. the signs of the coefficients. For details on the estimations see Appendix II, Tables 10-13. Due to the large number of estimations, only coefficients significant at least at the 5\% level are presented. Variable definitions are given in Appendix III.

* Administrative expenses per active contributor.

** Ranking by managed assets. A positive coefficient indicates a positive influence of smaller size on the dependent variable.

\footnotetext{
${ }^{23}$ To take account of heteroskedasticity, the Newey-West covariance matrix is applied. Despite the relative high number of observations, there is some indication of a deviation from the assumption of a normal distribution of the residuals. That is why all presented estimations are verified with robust regressions using a modified maximum likelihood estimator which accounts for non-normally distributed data. The results from applying the two methods show only small differences. For both methods the coefficients presented in Table 4 and Appendix II are at least significant at the 5 percent level. The regressions are performed with the software Eviews(C) 3.1. All robust regressions are done with the statistical package $\mathrm{R}$ 2.0.1.

${ }^{24}$ The regression models estimated are of the generic linear form $y=\alpha+\Sigma \beta_{k} X_{k}+\varepsilon$, with $y_{i}$ denoting the respective independent variable, $\alpha$ the constant, $\beta_{k}$ the coefficients of a set of determining variables $X_{k}$, and $\varepsilon$ the regression residual.
} 
Broadly speaking, the empirical evidence derived from the regressions lends support to the main theoretical considerations as well as to the comments made in the descriptive analysis. For equity shares, the disability and survivors' beneficiaries' ratios as well as reserves are strong determinants, carrying the expected signs. The estimations for real estate shares confirm these results with inverted signs. Administrative expenses are prominently influenced by the survivors' and exit benefits ratios and whether a pension fund is public and of the DC type. The last factor is also important for asset management expenses, together with shares held in different asset classes. The most pronounced positive linkage is seen for real estate investments, which may reflect high transaction costs due to a less liquid and less transparent real estate market. The influence of average age on the dependent variables equally supports the expectations, albeit suggesting a moderate influence.

The interpretation of the size of the regression coefficients is not entirely straightforward since the specifications of the variables vary. This applies in particular to the variable of pension fund size, which reflects a ranking by the volume of assets managed. Most notably, the estimations indicate significantly that smaller pension funds generally have higher administrative expenses than larger ones, which points to a potential of cost-saving economies of scale. Some further specific comments on the results of the estimations can be made as follows.

\section{Determinants of Asset Allocation}

The explanatory power of the models on the determinants of equity share differs markedly between the two years under consideration. While for the year 2000 the adjusted $\mathrm{R}^{2}$ reach satisfactory levels for a cross-section analysis, the adjusted $\mathrm{R}^{2}$ for 2002 are low. ${ }^{25}$ This likely reflects the massive stock market downturn between 2000 and 2002, which overshadowed the traditional linkages and the influence of the explanatory variables. In particular, the explanatory power of the models was reduced by the fact that reserve levels fell more sharply than the shares of assets exposed to the stock market. In addition, there was also a narrowing in the variation of the model variables, leaving less scope for explaining differences within the universe of pension funds.

Real estate investments as well as mortgage loans generate regular and less volatile cash flows that can be used for the financing of benefits payouts. ${ }^{26}$ The distinction made between total real estate holdings (including mortgage loans) and pure real estate investments shows only small differences for the coefficients (except for exit benefits, which include payouts of funds to finance private property) and has no influence on the signs of the parameters. Generally, the adjusted $\mathrm{R}^{2}$ are low, with the identified models explaining only about 7 to 11 percent of the observed variation.

Exit benefits are negatively related to real estate holdings. This might be explained by the fact that real estate investments cannot be liquidated immediately in order to finance exit

\footnotetext{
${ }^{25} \mathrm{R}^{2}$ is the percentage of variation of the dependent variable that can be explained by the OLS-model, controlled for the degrees of freedom.

${ }^{26}$ In addition, direct real estate investments increase the flexibility of the liquidity management by allowing pension funds to finance with outside capital.
} 
benefits. Therefore, higher exit benefits, for example due to higher expected labor turnover rates, tend to force the pension funds to invest in more liquid assets. This may also explain the positive relation with equity share.

There is a clear indication of the value of a reserve cushion for the capacity to assume market risks in investing. The cover ratio, which pits assets against liabilities, is primarily relevant for regulatory compliance and is apparently not very indicative for the allocation of assets. The negative sign for the year 2002 data may be due to the fact that pension funds with initially higher cover ratios and higher equity holdings were affected more strongly by the stock market downturn (primarily by valuation losses).

The fact that a pension fund is public equals lower equity shares and higher real estate investment. Their conservative investment strategy may partly reflect the higher average age within funds under public law. Plan type is not a statistically significant factor. This might be due to the fact that the Swiss occupational pension regulation includes performance parameters for DC funds, such as the minimum return guarantee and the conversion rate. The differences in their asset allocation decisions relative to DB plans are therefore small.

To further illustrate the relationships regarding the determinants of asset allocation, and for equity investments in particular, the following reaction analysis table spells out the estimated quantitative impact.

Table 5. Reaction Analysis for Equity Holdings

\begin{tabular}{llc}
\hline Change in ... & & $\begin{array}{c}\text { Resulting in a change of equity share } \\
\text { (in percentage points) }\end{array}$ \\
\hline Average age (contributors) & +1 year & -0.2 to -0.4 \\
& +5 years & -0.8 to -2.0 \\
Disability beneficiaries' ratio & +1 percentage point & -0.2 to -0.4 \\
& +2.5 percentage points & -0.4 to -1.0 \\
Reserves & +1 percentage point & +0.2 to +0.9 \\
& +10 percentage points & +2.2 to +8.6 \\
\hline
\end{tabular}

Notes:

See Annex III for definitions. The quoted ceteris paribus changes are based on estimations (2) to (6) in Appendix II (Table 10).

\section{Determinants of Costs}

The explanatory power of the models on cost determinants, as indicated by the adjusted $\mathrm{R}^{2}$, is satisfactory and somewhat higher for administrative expenses than for asset management costs. In line with earlier observations about financial market developments in the time period covered, the estimations on asset management expenses have a lower adjusted $\mathrm{R}^{2}$ for the 2002 sample than for the year 2000 . 
Public pension funds are shown to have significantly lower administrative expenses. This finding might reflect a better concentration of public pension funds on cost effective service provision rather than gaining market share. The result may, however, underestimate the costs actually incurred by these funds, due to less competitive pressure to separate out overhead expenses.

The estimates suggest a notable negative impact of DC pension fund type on both administrative and asset management expenses. This outcome for both cost categories seems to point to higher cost efficiency or cost control of DC plans in comparison with DB plans.

The data confirm a significant influence of pension fund size (as measured by rank according to assets under management) on the cost variables. ${ }^{27}$ While the expectations are supported for administrative costs, a small inverse influence is found for asset management costs. This latter evidence may reflect the fact that pension funds already make considerable use of instruments for pooling assets such as setting up collective investment foundations. They also often outsource parts or even all of their asset management, which is a cost efficient alternative for in-house asset management especially for smaller pension funds. The potential for economies of scale is therefore already exploited in various ways.

\section{Conclusions}

This analysis of data from the Swiss Pension Statistic offers further insight on the impact of an aging population on pension funds' investment behavior. The empirical estimations broadly confirm a priori expectations, even if limits to the analysis such as the heterogeneity of the Swiss pension fund landscape, the challenging market environment in the time period considered, and accounting differences within the sample have to be acknowledged.

A main finding of the analysis is the observed significant negative relationship between the short-term balance sheet liabilities of Swiss pension funds, reflecting their age profile and payments obligations, and their holdings of risky assets (equities). This might reflect the legal requirement for pension funds to take account of the liability side in their asset allocation, but also the widespread use of ALM techniques in general. The evidence supports the view that aging may lead to increased risk aversion and thus to a lower engagement of institutional investors in equities. Based on the empirical evidence, a substantial reserve cushion could moderate this conservative investment bias by raising risk-bearing capacity.

The analysis also indicates an influence of age and liabilities on other asset holdings. Pension funds with a high number of disability, survivors', and old-age benefits recipients tend to be more strongly invested in real estate, which provides regular and less volatile cash flows in order to meet payments obligations. Furthermore, there seems to be a strong link between disability benefits and asset allocation. This is somewhat unexpected, since pension funds should ideally treat insurance premiums and saving contributions separately. A large number of disability cases should lead to an increase in premiums but should not influence the asset

\footnotetext{
${ }^{27}$ The small coefficients for size are due to the definition of this explanatory variable, limiting the interpretation of the findings.
} 
allocation of pension funds. The observed relationship therefore provides evidence of crosssubsidization between different risk categories.

When looking at pension funds' administrative expenses, the analysis shows that legal form and pension plan type are important. These expenses are shown to be lower for public and DC plans. For public pension funds any cost savings may cancel out, however, since these funds are still predominantly of the DB type. Factors related to age and payments obligations as well as pension fund size (in terms of assets managed) have the expected positive impact on administrative costs. In order for a pension fund to realize further cost economies, these factors would thus primarily need to be influenced.

The results also point to the potential that a conservative investment bias (of pension funds with a more mature age profile with limited ability to bear market risks) might be reinforced in case of a significant market downturn. If regulation, including accounting rules, does not allow for the building-up of sufficient reserves that can serve as a shock absorber and for a temporary relaxation of cover ratios, such pension providers are forced to sell equities in a bearish market. Regulators and supervisors are faced with the delicate task of assuring the soundness of the system, allowing for investments with significant return potential (entailing certain risks), and at the same time preventing pro-cyclical market behavior of pension providers.

There are several ways that the present analysis could be refined and extended. First, a stronger case for the conclusions drawn could be made with a longer observation period. Second, a better understanding on the relevant determinants and linkages may be gained by including a broader set of explanatory variables. For example, taking account of investment returns could provide evidence on how actively assets are moved between asset classes in pursuit of an optimal portfolio mix. Similarly, there may be further insights from looking at the choice between domestic and foreign assets, as investing abroad in principle offers additional opportunities for diversifying risk. With a weakening of the investment home bias of pension funds in many countries, including in Switzerland, such considerations gain in importance. Third, empirical case studies for other countries with a similar focus would be useful. Such further work must duly consider the distinct country-specific regulatory framework that influences pension funds' payments obligations and investment decisions. 


\section{Appendix I. Key Indicators from the Swiss Pension Statistic}

Table 6. Benefits Ratios of Different Types of Pension Funds

\begin{tabular}{|c|c|c|c|c|c|c|c|c|c|c|c|c|c|c|}
\hline & \multicolumn{2}{|c|}{$\begin{array}{c}\text { Old-age } \\
\text { dependency } \\
\text { ratio }\end{array}$} & \multicolumn{2}{|c|}{$\begin{array}{l}\text { Dependency } \\
\text { ratio }\end{array}$} & \multicolumn{2}{|c|}{$\begin{array}{c}\text { Expense } \\
\text { ratio } \\
\text { (in CHF } \\
1 \text { '000) }\end{array}$} & \multicolumn{2}{|c|}{$\begin{array}{l}\text { Lump sum } \\
\text { beneficia- } \\
\text { ries' ratio } \\
\text { (in } \%)\end{array}$} & \multicolumn{2}{|c|}{$\begin{array}{l}\text { Survivors' } \\
\text { beneficia- } \\
\text { ries' ratio } \\
\text { (in \%) }\end{array}$} & \multicolumn{2}{|c|}{$\begin{array}{l}\text { Disability } \\
\text { beneficia- } \\
\text { ries' ratio } \\
\text { (in \%) }\end{array}$} & \multicolumn{2}{|c|}{$\begin{array}{c}\text { Exit benefits } \\
\text { ratio } \\
\text { (in } \mathrm{CHF} \\
\left.1{ }^{\prime} 000\right)\end{array}$} \\
\hline & 00 & 02 & 00 & 02 & 00 & 02 & 00 & 02 & 00 & 02 & 00 & 02 & 00 & 02 \\
\hline \multicolumn{15}{|l|}{ Characteristic } \\
\hline Autonomous 1 & 0.22 & 0.22 & 0.35 & 0.37 & 7.00 & 7.87 & 1.22 & 0.70 & 7.48 & 7.33 & 2.94 & 3.34 & 6.37 & 5.75 \\
\hline Autonomous 2 & 0.11 & 0.12 & 0.20 & 0.20 & 3.19 & 3.54 & 1.06 & 0.83 & 3.39 & 3.58 & 2.21 & 2.46 & 6.84 & 6.67 \\
\hline $\begin{array}{l}\text { Partial auto- } \\
\text { nomous } 1\end{array}$ & 0.04 & 0.05 & 0.11 & 0.13 & 1.33 & 1.61 & 1.79 & 1.74 & 0.60 & 0.68 & 1.71 & 2.25 & 5.34 & 5.46 \\
\hline $\begin{array}{l}\text { Partial auto- } \\
\text { nomous } 2\end{array}$ & 0.00 & 0.01 & 0.05 & 0.07 & 0.53 & 0.67 & 1.90 & 2.07 & 0.00 & 0.00 & 1.47 & 1.83 & 5.67 & 5.29 \\
\hline Collective & 0.06 & 0.07 & 0.13 & 0.15 & 1.36 & 1.67 & 1.52 & 1.15 & 0.92 & 1.15 & 2.09 & 2.61 & 5.04 & 4.72 \\
\hline \multicolumn{15}{|l|}{ Type } \\
\hline DB & 0.22 & 0.23 & 0.35 & 0.36 & 8.54 & 9.52 & 1.20 & 0.72 & 7.01 & 7.16 & 2.48 & 2.50 & 6.93 & 5.69 \\
\hline $\mathrm{DC}$ & 0.04 & 0.04 & 0.11 & 0.12 & 1.13 & 1.44 & 1.60 & 1.48 & 0.74 & 0.99 & 2.06 & 2.46 & 5.90 & 5.83 \\
\hline \multicolumn{15}{|l|}{ Law } \\
\hline Private & 0.05 & 0.06 & 0.13 & 0.14 & 1.44 & 1.73 & 1.59 & 1.40 & 1.11 & 1.33 & 2.12 & 2.44 & 6.18 & 5.92 \\
\hline Public & 0.23 & 0.23 & 0.37 & 0.37 & 8.90 & 9.47 & 0.39 & 0.35 & 7.71 & 7.44 & 2.61 & 2.82 & 4.89 & 4.81 \\
\hline Total & 0.06 & 0.07 & 0.14 & 0.15 & 1.59 & 1.92 & 1.53 & 1.35 & 1.39 & 1.15 & 2.16 & 2.61 & 6.05 & 5.79 \\
\hline $\begin{array}{l}\text { Notes: } \\
\text { See Appendix I } \\
\text { beneficiaries' ra } \\
\text { ratio. Medians }\end{array}$ & pre & 110 & allo & . & 101 & 110 & 01 & 101 & 2 & 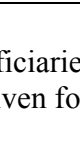 & $1 \mathrm{de}$ & 5 & rs' & \\
\hline
\end{tabular}

Table 7. Age Profile of Pension Funds

\begin{tabular}{|c|c|c|c|c|c|c|}
\hline & \multicolumn{2}{|c|}{ Average age I } & \multicolumn{2}{|c|}{ Average age II } & \multicolumn{2}{|c|}{ Average age III } \\
\hline & 2000 & 2002 & 2000 & 2002 & 2000 & 2002 \\
\hline \multicolumn{7}{|l|}{ Characteristic } \\
\hline Autonomous 1 & 47.5 & 47.8 & 42.1 & 42.4 & 47.8 & 48.1 \\
\hline Autonomous 2 & 44.3 & 44.7 & 41.4 & 41.7 & 44.6 & 45.0 \\
\hline Partial autonomous 1 & 43.6 & 44.1 & 41.7 & 42.2 & 43.9 & 44.5 \\
\hline Partial autonomous 2 & 42.3 & 42.5 & 41.6 & 42.0 & 42.5 & 42.8 \\
\hline Collective & 44.0 & 44.9 & 42.0 & 42.5 & 44.2 & 45.1 \\
\hline \multicolumn{7}{|l|}{ Type } \\
\hline DB & 47.8 & 47.9 & 42.3 & 42.5 & 47.9 & 48.1 \\
\hline $\mathrm{DC}$ & 43.3 & 43.8 & 41.7 & 42.0 & 43.6 & 44.2 \\
\hline \multicolumn{7}{|l|}{ Law } \\
\hline Private & 43.7 & 44.2 & 41.7 & 42.0 & 44.0 & 44.5 \\
\hline Public & 48.6 & 49.0 & 43.0 & 43.7 & 48.7 & 49.2 \\
\hline Total & 43.9 & 44.4 & 41.8 & 42.1 & 44.2 & 44.7 \\
\hline
\end{tabular}


Table 8. Asset Allocation and Financial Soundness

\begin{tabular}{|c|c|c|c|c|c|c|c|c|c|c|c|c|}
\hline & \multicolumn{2}{|c|}{ Cash } & \multicolumn{2}{|c|}{ Real Estate } & \multicolumn{2}{|c|}{ Bonds } & \multicolumn{2}{|c|}{ Equity } & \multicolumn{2}{|c|}{ Reserves } & \multicolumn{2}{|c|}{$\begin{array}{l}\text { Cover ratio } \\
\text { (in \%) }\end{array}$} \\
\hline & 2000 & 2002 & 2000 & 2002 & 2000 & 2002 & 2000 & 2002 & 2000 & 2002 & 2000 & 2002 \\
\hline \multicolumn{13}{|l|}{ Characteristic } \\
\hline Autonomous 1 & 0.04 & 0.05 & 0.19 & 0.22 & 0.36 & 0.40 & 0.30 & 0.23 & 0.11 & 0.03 & 106.0 & 100.0 \\
\hline Autonomous 2 & 0.04 & 0.06 & 0.11 & 0.15 & 0.42 & 0.43 & 0.30 & 0.24 & 0.09 & 0.03 & 108.0 & 100.0 \\
\hline $\begin{array}{l}\text { Partial auto- } \\
\text { nomous } 1\end{array}$ & 0.06 & 0.08 & 0.06 & 0.09 & 0.42 & 0.44 & 0.28 & 0.24 & 0.05 & 0.01 & 109.0 & 100.0 \\
\hline $\begin{array}{l}\text { Partial auto- } \\
\text { nomous } 2\end{array}$ & 0.06 & 0.09 & 0.06 & 0.09 & 0.36 & 0.37 & 0.23 & 0.17 & 0.05 & 0.01 & 113.0 & 100.0 \\
\hline Collective & n.a. & n.a. & n.a. & n.a. & n.a. & n.a. & n.a. & n.a. & n.a. & n.a. & 108.0 & 104.0 \\
\hline \multicolumn{13}{|l|}{ Type } \\
\hline DB & 0.04 & 0.05 & 0.16 & 0.16 & 0.39 & 0.40 & 0.29 & 0.24 & 0.09 & 0.03 & 107.0 & 100.0 \\
\hline $\mathrm{DC}$ & 0.05 & 0.07 & 0.10 & 0.12 & 0.40 & 0.42 & 0.27 & 0.22 & 0.07 & 0.02 & 108.0 & 100.0 \\
\hline \multicolumn{13}{|l|}{$L a w$} \\
\hline Private & 0.05 & 0.07 & 0.10 & 0.12 & 0.40 & 0.42 & 0.28 & 0.22 & 0.07 & 0.02 & 109.0 & 100.0 \\
\hline Public & 0.03 & 0.05 & 0.22 & 0.25 & 0.29 & 0.30 & 0.28 & 0.21 & 0.08 & 0.02 & 100.0 & 93.5 \\
\hline Total & 0.05 & 0.07 & 0.10 & 0.13 & 0.39 & 0.41 & 0.28 & 0.22 & 0.07 & 0.02 & 108.0 & 100.0 \\
\hline
\end{tabular}

Notes:

See Appendix III for definitions. Medians are shown for all variables.

Table 9. Costs and Size of Pension Funds

\begin{tabular}{|c|c|c|c|c|c|c|c|c|}
\hline & \multicolumn{2}{|c|}{$\begin{array}{l}\text { Administrative } \\
\text { expenses I }\end{array}$} & \multicolumn{2}{|c|}{$\begin{array}{l}\text { Administrative } \\
\text { expenses II }\end{array}$} & \multicolumn{2}{|c|}{$\begin{array}{l}\text { Asset management } \\
\text { expenses }\end{array}$} & \multicolumn{2}{|c|}{$\begin{array}{c}\text { Assets } \\
\text { (in CHF 1'000) }\end{array}$} \\
\hline & 2000 & 2002 & 2000 & 2002 & 2000 & 2002 & 2000 & 2002 \\
\hline \multicolumn{9}{|l|}{ Characteristic } \\
\hline Autonomous 1 & 0.30 & 0.29 & 0.41 & 0.40 & 0.31 & 0.31 & $133^{\prime} 401$ & $137^{\prime} 766$ \\
\hline Autonomous 2 & 0.34 & 0.37 & 0.44 & 0.46 & 0.32 & 0.33 & 49'929 & $48^{\prime} 067$ \\
\hline $\begin{array}{l}\text { Partial auto- } \\
\text { nomous } 1\end{array}$ & 0.43 & 0.41 & 0.50 & 0.50 & 0.10 & 0.20 & $12^{\prime} 646$ & $11^{\prime} 679$ \\
\hline $\begin{array}{l}\text { Partial auto- } \\
\text { nomous } 2\end{array}$ & 0.34 & 0.38 & 0.38 & 0.42 & 0.12 & 0.13 & $6^{\prime} 220$ & 6'099 \\
\hline Collective & 0.14 & 0.16 & 0.17 & 0.20 & 0.02 & 0.02 & n.a. & n.a. \\
\hline \multicolumn{9}{|l|}{ Type } \\
\hline DB & 0.37 & 0.38 & 0.48 & 0.50 & 0.35 & 0.38 & 91'093 & $80^{\prime} 905$ \\
\hline $\mathrm{DC}$ & 0.35 & 0.36 & 0.37 & 0.39 & 0.15 & 0.20 & $16^{\prime} 322$ & $17 ' 597$ \\
\hline \multicolumn{9}{|l|}{ Law } \\
\hline Private & 0.37 & 0.37 & 0.39 & 0.41 & 0.18 & 0.22 & 21'099 & $21^{\prime} 805$ \\
\hline Public & 0.24 & 0.26 & 0.35 & 0.34 & 0.21 & 0.22 & $115^{\prime} 008$ & $123^{\prime} 364$ \\
\hline Total & 0.35 & 0.36 & 0.38 & 0.40 & 0.18 & 0.22 & $23 ' 239$ & $24 ' 191$ \\
\hline
\end{tabular}

Notes:

See Appendix III for definitions. Medians are shown for all variables. 


\section{Appendix II. OLS-Regression Estimates}

Table 10. Regression Estimates for Equity Share

\begin{tabular}{|c|c|c|c|c|c|c|c|}
\hline Year & & 20 & & & & 2002 & \\
\hline & (1) & (2) & (3) & (4) & (5) & (6) & (7) \\
\hline Dependent variable & & Equ & & & & Equity & \\
\hline $\mathrm{N}$ & 2137 & 2137 & 943 & 943 & 2035 & 921 & 921 \\
\hline Constant & $\begin{array}{l}0.34003 \\
(12.35)\end{array}$ & $\begin{array}{c}0.363130 \\
(9.35)\end{array}$ & $\begin{array}{c}0.42385 \\
(7.22)\end{array}$ & $\begin{array}{c}0.31432 \\
(4.57)\end{array}$ & $\begin{array}{c}0.329418 \\
(10.23)\end{array}$ & $\begin{array}{c}0.39199 \\
(7.60)\end{array}$ & $\begin{array}{c}0.35472 \\
(9.77)\end{array}$ \\
\hline Average age III & $\begin{array}{l}-0.00177 \\
(-3.09)\end{array}$ & & & & & & \\
\hline Average age II & & $\begin{array}{c}-0.002518 \\
(-2.71)\end{array}$ & $\begin{array}{c}-0.00390 \\
(-2.78)\end{array}$ & $\begin{array}{c}-0.00398 \\
(-2.61)\end{array}$ & $\begin{array}{c}-0.001661 \\
(-2.17)\end{array}$ & $\begin{array}{c}-0.00311 \\
(-2.57)\end{array}$ & \\
\hline $\begin{array}{l}\text { Disability beneficiaries' } \\
\text { Ratio }\end{array}$ & $\begin{array}{c}-0.29992 \\
(-3.70)\end{array}$ & $\begin{array}{c}-0.321178 \\
(-3.98)\end{array}$ & $\begin{array}{c}-0.38025 \\
(-3.00)\end{array}$ & $\begin{array}{c}-0.36245 \\
(-2.79)\end{array}$ & $\begin{array}{c}-0.169252 \\
(-2.86)\end{array}$ & $\begin{array}{c}-0.28295 \\
(-3.41)\end{array}$ & $\begin{array}{c}-0.35629 \\
(-4.57)\end{array}$ \\
\hline $\begin{array}{l}\text { Survivors' beneficiaries' } \\
\text { Ratio }\end{array}$ & & & $\begin{array}{c}-0.11355 \\
(-3.13)\end{array}$ & $\begin{array}{c}-0.11504 \\
(-3.12)\end{array}$ & & & \\
\hline Exit benefits ratio & $\begin{array}{c}0.00074 \\
(3.13)\end{array}$ & $\begin{array}{c}0.000739 \\
(3.13)\end{array}$ & $\begin{array}{c}0.00114 \\
(2.66)\end{array}$ & $\begin{array}{c}0.00119 \\
(2.88)\end{array}$ & & & \\
\hline Reserves & $\begin{array}{l}0.73082 \\
(14.43)\end{array}$ & $\begin{array}{c}0.728676 \\
(14.32)\end{array}$ & $\begin{array}{l}0.85933 \\
(13.67)\end{array}$ & $\begin{array}{l}0.83037 \\
(12.76)\end{array}$ & $\begin{array}{l}0.221761 \\
(3.49)\end{array}$ & $\begin{array}{c}0.29847 \\
(3.59)\end{array}$ & $\begin{array}{c}0.34089 \\
(4.10)\end{array}$ \\
\hline Cover ratio & & & & $\begin{array}{c}0.00104 \\
(3.55)\end{array}$ & & & $\begin{array}{c}-0.00094 \\
(-2.52)\end{array}$ \\
\hline Law: public & $\begin{array}{c}-0.03496 \\
(-3.42)\end{array}$ & $\begin{array}{c}-0.035358 \\
(-3.43)\end{array}$ & $\begin{array}{c}-0.02727 \\
(-2.61)\end{array}$ & & $\begin{array}{c}-0.039033 \\
(-3.81)\end{array}$ & $\begin{array}{c}-0.03240 \\
(-3.07)\end{array}$ & $\begin{array}{c}-0.04262 \\
(-3.83)\end{array}$ \\
\hline Plan type: DC & & & & & & & \\
\hline Size * & $\begin{array}{c}-0.00005 \\
(-7.78)\end{array}$ & $\begin{array}{c}-0.000042 \\
(-7.15)\end{array}$ & $\begin{array}{c}-0.00008 \\
(-4.92)\end{array}$ & $\begin{array}{c}-0.00008 \\
(-4.88)\end{array}$ & $\begin{array}{c}-0.000044 \\
(-7.78)\end{array}$ & $\begin{array}{c}-0.00006 \\
(-4.12)\end{array}$ & $\begin{array}{c}-0.00005 \\
(-3.60)\end{array}$ \\
\hline Included observations & 2061 & 2060 & 903 & 883 & 1965 & 892 & 900 \\
\hline Adj. R-squared & 0.182992 & 0.183216 & 0.27842 & 0.28634 & 0.051527 & 0.060255 & 0.052232 \\
\hline
\end{tabular}

Notes:

See Appendix III for definitions. Regression coefficients are reported, t-values are shown in brackets. Only coefficients significant at least at the 5\% level are presented. Estimations (1), (2), and (5) include autonomous and partially autonomous funds. Estimations (3), (4), (6), and (7) include only autonomous funds.

* A negative coefficient for pension fund size indicates a negative influence of smaller size on equity share. 
Table 11. Regression Estimates for Real Estate Investment

\begin{tabular}{|c|c|c|c|c|}
\hline Year & & 2000 & & 2002 \\
\hline & (8) & (9) & $(10)$ & (11) \\
\hline Dependent variable & Real Estate pure & Real Estate & Real Estate & Real Estate pure \\
\hline $\mathrm{N}$ & 2137 & 943 & 943 & 2035 \\
\hline Constant & $\begin{array}{c}0.131702 \\
(16.16)\end{array}$ & $\begin{array}{c}0.075985 \\
(1.50)\end{array}$ & $\begin{array}{c}0.164207 \\
(3.08)\end{array}$ & $\begin{array}{c}0.151321 \\
(17.75)\end{array}$ \\
\hline Average age III & & $\begin{array}{c}0.002883 \\
(2.50)\end{array}$ & $\begin{array}{c}0.003873 \\
(3.54)\end{array}$ & \\
\hline Disability beneficiaries' ratio & $\begin{array}{c}0.406387 \\
(4.19)\end{array}$ & $\begin{array}{c}0.478224 \\
(2.58)\end{array}$ & $\begin{array}{c}0.356596 \\
(1.99)\end{array}$ & $\begin{array}{c}0.309295 \\
(3.26)\end{array}$ \\
\hline Survivors' beneficiaries' ratio & $\begin{array}{c}0.18563 \\
(3.93)\end{array}$ & $\begin{array}{c}0.194123 \\
(2.99)\end{array}$ & $\begin{array}{c}0.175369 \\
(2.69)\end{array}$ & $\begin{array}{c}0.223112 \\
(5.00)\end{array}$ \\
\hline Exit benefits ratio & $\begin{array}{c}-0.000944 \\
(-4.85)\end{array}$ & $\begin{array}{c}-0.002436 \\
(-5.56)\end{array}$ & $\begin{array}{c}-0.002716 \\
(-6.12)\end{array}$ & $\begin{array}{c}-0.000745 \\
(-4.08)\end{array}$ \\
\hline Reserves & & $\begin{array}{c}-0.312813 \\
(-3.86)\end{array}$ & & \\
\hline Cover ratio & & & $\begin{array}{c}-0.001509 \\
(-4.63)\end{array}$ & \\
\hline Law: public & $\begin{array}{c}0.028412 \\
(2.05)\end{array}$ & $\begin{array}{c}0.037607 \\
(2.36)\end{array}$ & & $\begin{array}{c}0.03380 \\
(2.40)\end{array}$ \\
\hline Plan type: DC & & & & \\
\hline Size * & $\begin{array}{c}-0.000027 \\
(-4.72)\end{array}$ & $\begin{array}{c}-0.000032 \\
(-1.76)\end{array}$ & & $\begin{array}{c}-0.000032 \\
(-5.16)\end{array}$ \\
\hline Included observations & 2107 & 904 & 884 & 2007 \\
\hline Adj. R-squared & 0.066271 & 0.112497 & 0.113523 & 0.068462 \\
\hline
\end{tabular}

Notes:

See Appendix III for definitions. Regression coefficients are reported, t-values are shown in brackets. Only coefficients significant at least at the 5\% level are presented. Estimations (8) and (11) include autonomous and partially autonomous funds. Estimations (9) and (10) include only autonomous funds.

* A negative coefficient for pension fund size indicates a negative influence of smaller size on real estate share. 
Table 12. Regression Estimates for Administrative Costs

\begin{tabular}{|c|c|c|c|c|}
\hline Year & & & & \\
\hline & $(12)$ & (13) & (14) & $(15)$ \\
\hline Dependent variable & Administ & penses II & Administ & penses II \\
\hline $\mathrm{N}$ & 2137 & 943 & 2035 & 921 \\
\hline Constant & -0.401867 & -0.819764 & -0.799221 & -0.887143 \\
\hline & $(-2.31)$ & $(-2.33)$ & $(-4.41)$ & $(-2.84)$ \\
\hline Average age III & 0.019167 & & 0.026753 & \\
\hline & $(4.82)$ & & $(6.54)$ & \\
\hline Average age II & & 0.027671 & & 0.029249 \\
\hline & & $(3.21)$ & & $(3.80)$ \\
\hline Survivors' beneficiaries' ratio & 1.064379 & 1.240054 & 0.795611 & 1.050965 \\
\hline & $(4.62)$ & $(5.58)$ & $(3.12)$ & $(3.46)$ \\
\hline Exit benefits ratio & 0.008557 & 0.018333 & 0.00906 & 0.02099 \\
\hline & $(4.91)$ & $(4.44)$ & $(4.57)$ & $(6.40)$ \\
\hline Law: public & -0.265851 & -0.201486 & -0.23061 & -0.183253 \\
\hline & $(-7.19)$ & $(-4.78)$ & $(-4.65)$ & $(-3.62)$ \\
\hline Plan type: DC & -0.178806 & -0.120574 & -0.19048 & -0.169993 \\
\hline & $(-4.23)$ & $(-2.60)$ & $(-4.86)$ & $(-4.03)$ \\
\hline $\operatorname{Size}^{*}$ & 0.000179 & 0.000209 & 0.00027 & 0.000267 \\
\hline & $(7.01)$ & $(3.04)$ & $(10.00)$ & $(4.41)$ \\
\hline Included observations & 2025 & 893 & 1917 & 861 \\
\hline Adj. R-squared & 0.159502 & 0.235939 & 0.195336 & 0.217677 \\
\hline
\end{tabular}

Notes:

See Appendix III for definitions. Regression coefficients are reported, t-values are shown in brackets. Only coefficients significant at least at the 5\% level are presented. Estimations (12) and (14) include autonomous and partial autonomous funds. Estimations (13) and (15) include only autonomous funds.

* A positive coefficient for pension fund size indicates a positive influence of smaller size on administrative costs. 
Table 13. Regression Estimates for Asset Management Costs

\begin{tabular}{l|cc|cc}
\hline Year & \multicolumn{2}{|c|}{2000} & \multicolumn{2}{c}{2002} \\
\hline Dependent variable & $(16)$ & $(17)$ & $(18)$ & $(19)$ \\
$\mathrm{N}$ & Asset management expenses & Asset management expenses \\
& 2137 & 943 & 2035 & 921 \\
Constant & & & & \\
& 0.242533 & 0.10256 & 0.268508 & 0.003553 \\
Equity & $(4.58)$ & $(1.17)$ & $(4.56)$ & $(0.05)$ \\
& 0.496031 & 0.728178 & 0.561837 & 0.991896 \\
Real estate & $(4.66)$ & $(2.91)$ & $(4.08)$ & $(3.88)$ \\
& 2.294781 & 2.421016 & 1.770137 & 1.902479 \\
Bonds & $(12.53)$ & $(8.19)$ & $(10.12)$ & $(8.37)$ \\
Plan type: DC & & & & 0.333362 \\
Size * & & & & $(2.40)$ \\
& & & & \\
Included observations & & & & $(-2.114089$ \\
Adj. R-squared & & & & \\
\hline
\end{tabular}

Notes:

See Appendix III for definitions. Regression coefficients are reported, t-values are shown in brackets. Only coefficients significant at least at the 5\% level are presented. Estimations (16) and (18) include autonomous and partial autonomous funds. Estimations (17) and (19) include only autonomous funds.

* A negative coefficient for pension fund size indicates a negative influence of smaller size on asset management costs. 


\section{Appendix III: Definitions of the Variables}

\begin{tabular}{|c|c|}
\hline Variable & Definition \\
\hline $\begin{array}{l}\text { Administrative } \\
\text { expenses I }\end{array}$ & $\begin{array}{l}\text { Administrative costs (e.g. salaries, IT, or rents, costs for external expert } \\
\text { opinions, fees charged by insurers) in CHF 1'000 divided by the sum of active } \\
\text { contributors and total benefits recipients }\end{array}$ \\
\hline $\begin{array}{l}\text { Administrative } \\
\text { expenses II }\end{array}$ & Administrative costs in CHF 1'000 divided by the sum of active contributors \\
\hline Assets & Assets under management in CHF 1'000 \\
\hline $\begin{array}{l}\text { Asset management } \\
\text { expenses }\end{array}$ & $\begin{array}{l}\text { Expenses for managing securities and real estate investments, interest } \\
\text { payments, and bank charges in CHF 1'000 divided by the sum of active } \\
\text { contributors and total benefits recipients }\end{array}$ \\
\hline Average age I & $\begin{array}{l}\text { Average age weighted by the absolute number of active contributors and old- } \\
\text { age pension recipients }\end{array}$ \\
\hline Average age II & Average age weighted by the number of active contributors \\
\hline Average age III & $\begin{array}{l}\text { Average age weighted by the number of active contributors, disability benefits } \\
\text { recipients, and old-age pension recipients }\end{array}$ \\
\hline Bonds & Bond holdings (direct and collective) as share of total assets \\
\hline Cash & Liquid assets as a share of total assets \\
\hline Cover ratio & $\begin{array}{l}\text { Ratio between the assets and the present value of all future liabilities as } \\
\text { indicated in the actuarial expert opinion }\end{array}$ \\
\hline Dependency ratio & $\begin{array}{l}\text { Number of total benefits recipients divided by the number of active } \\
\text { contributors }\end{array}$ \\
\hline $\begin{array}{l}\text { Disability bene- } \\
\text { ficiaries' ratio }\end{array}$ & $\begin{array}{l}\text { Number of disability benefits recipients divided by the number of active } \\
\text { contributors }\end{array}$ \\
\hline Equity & Equity holdings (direct and collective) as a share of total assets \\
\hline Expense ratio & Pension payments in CHF 1'000 divided by the number of active contributors \\
\hline Exit benefits ratio & $\begin{array}{l}\text { Exit benefits in CHF 1'000 divided by the number of active contributors; exit } \\
\text { benefits include withdrawal benefits due to job turnovers, cash payouts, and } \\
\text { payouts for mortgage financing }\end{array}$ \\
\hline Law & $0=$ pension fund under private law, $1=$ pension fund under public law \\
\hline $\begin{array}{l}\text { Lump sum bene- } \\
\text { ficiaries' ratio }\end{array}$ & $\begin{array}{l}\text { Number of lump sum benefits recipients divided by the number of active } \\
\text { contributors }\end{array}$ \\
\hline $\begin{array}{l}\text { Old-age dependency } \\
\text { ratio }\end{array}$ & Number of pensioners divided by the number of active contributors \\
\hline Plan type & $0=$ defined benefit $(\mathrm{DB}), 1=$ defined contribution $(\mathrm{DC})$ \\
\hline Real estate & $\begin{array}{l}\text { Direct and collective real estate investments in Switzerland and abroad plus } \\
\text { mortgages in Switzerland and abroad (direct and collective) as a share of total } \\
\text { assets }\end{array}$ \\
\hline Real estate pure & $\begin{array}{l}\text { Direct and collective real estate investments in Switzerland and abroad as a } \\
\text { share of total assets }\end{array}$ \\
\hline Reserves & Solvency margin as a share of total assets (equal total liabilities) \\
\hline Size & Ranking by assets managed, with 1 being the biggest pension fund \\
\hline $\begin{array}{l}\text { Survivors' bene- } \\
\text { ficiaries' ratio }\end{array}$ & $\begin{array}{l}\text { Number of survivors' benefits recipients divided by the number of active } \\
\text { contributors }\end{array}$ \\
\hline
\end{tabular}




\section{References}

Alestalo, Noora, and Vesa Puttonen, 2006, "Asset Allocation in Finnish Pension Funds," Journal of Pension Economics and Finance, Vol. 5 (1), pp. 27-44.

Allsopp, Christopher, and Nicholas Barr (eds.), 2006, Pensions, Oxford Review of Economic Policy, Vol. 22 (1).

Barr, Nicholas, 2002, "Reforming Pensions: Myths, Truths, and Policy Choices," International Social Security Review, Vol. 55 (2), pp. 3-36.

Bakshi, Gurdip S., and Zhiwu Chen, 1994, "Baby Boom, Population Aging, and Capital Markets," Journal of Business, 67 (2), pp. 165-202.

Birchler, Urs, and Nicole Allenspach, 2003, „Pensionskassen haben Börsenbaisse nicht verstärkt,“ Finanz und Wirtschaft, August 9 2003, Zürich.

Bodie, Zvi, 1995, “On the Risks of Stocks in the Long Run,” Financial Analysts Journal, Vol. 51 (3), pp. 18-22.

Börsch-Supan, Axel, Florian Heiss, Alexander Ludwig, and Joachim Winter, 2002, Pension Reform, Capital Markets, and the Rate of Return, Mannheim Research Institute for the Economics of Aging (MEA), University of Mannheim.

Campbell, John Y., and Luis M. Viceira, 2002, Strategic Asset Allocation - Portfolio Choice for Long-Term Investors, Oxford University Press.

Chun, Gregory H., Brian A. Ciochetti, and James D. Shilling, 2000, "Pension-Plan Real Estate Investment in an Asset-Liability Framework," Real Estate Economics, Vol. 28 (3), pp. 467-491.

Cai, Junning, 2004, Baby Boom, Asset Market Meltdown and Liquidity Trap, University of Hawaii, Department of Economics.

Davis, E. Philip, and Christine Li, 2003, Demographics and Financial Asset Prices in the Major Industrial Economies, Brunel University, London.

Diamond, Peter A., 1999, "Administrative Costs and Equilibrium Charges with Individual Accounts," NBER Working Paper No. 7550, National Bureau of Economic Research, Cambridge.

Federal Office of Social Insurance, 2003, Schweizerische Sozialversicherungsstatistik, Bern.

Federal Statistical Office, 2002, 2004, and 2006, Schweizerische Pensionskassenstatistik, Neuchâtel.

Feldstein, Martin, 2005, "Structural Reform of Social Security," Journal of Economic Perspectives, Vol. 19 (2), pp. 33-55. 
Gerber, David S., 2002, Freie Pensionskassenwahl in der schweizerischen Altersvorsorge. Ökonomische Analyse eines Systemwechsels zu einer wettbewerblichen Gestaltung der zweiten Säule, Verlag Rüegger, Chur/Zürich.

Gerber, David S., and René Weber, 2004, "Rentenfinanzierung mit Risiken,“ Schweizer Bank, October, pp. 44-46.

Groome, Todd, Nicolas Blancher, and Parmeshwar Ramlogan, 2006, “Aging and Financial Markets: Government as Risk Manager," Finance and Development, September, International Monetary Fund, pp. 44-47.

Groome et al., 2006, "The Limits of Market-Based Risk Transfer and Implications for Managing Systemic Risks," IMF Working Paper 06/217, International Monetary Fund, Washington.

Group of Ten Deputies, 2005, Ageing and Pension System Reform: Implications for Financial Markets and Economic Policies, www.bis.org/publ/gten09.htm, Basel.

IMF, 2004, Risk Management and the Pension Fund Industry, in: Global Financial Stability Report, Chapter III, September, International Monetary Fund, Washington.

James, Estelle, Gary Ferrier, James Smalhout, and Dimitri Vittas, 1999, Mutual Funds and Institutional Investments: "What is the Most Efficient Way to Set up Individual Accounts in a Social Security System?" NBER Working Paper No. 7049, National Bureau of Economic Research, Cambridge.

Mc Morrow, Kieran, and Werner Röger, 2003, Economic and Financial Market Consequences of Ageing Populations, European Economy, Economic Paper No. 182, European Commission, Brussels.

OECD, 2004, Ageing and Financial Markets, Financial Market Trends No. 86, March 2004, Organisation for Economic Co-operation and Development, Paris.

OECD, 2005, Final Taxonomy for Private Pensions, OECD Working Party on Private Pensions, Organisation for Economic Co-operation and Development, Paris.

Poterba, James M., 2001, "Demographic Structure and Asset Returns," Review of Economics and Statistics, Vol. 83 (4) pp. 565-584.

Schmid, Heinz, 2004, Expertise Überschussverteilung: Schlussbericht, Parlamentarische Verwaltungskontrollstelle, Parlamentsdienste, Bern.

Schweizerische Kammer der Pensionskassen-Experten, 2005, Stellungnahme zum technischen Zinssatz bei Vorsorgeeinrichtungen, www.kammer-pk-experten.ch, Basel. 